\title{
EFFECT OF LIGHT, TEMPERATURE AND SCARIFICATION ON THE GERMINATIVE CAPACITY AND INITIAL GROWTH OF Myroxylon balsamum (L.) HARMS ${ }^{1}$
}

\author{
SOPHIA LOAYZA-CABEZAS ${ }^{2 *}$, DANTE ARTURO RODRIGUEZ-TREJO ${ }^{3}$, ELIZABETH HERNÁNDEZ-ACOSTA ${ }^{4}$, \\ JUAN ALMARÁZ SUÁREZ
}

\begin{abstract}
Myroxylon balsamum is a valuable tropical tree; besides the good quality of its timber it also provides valuable nontimber forest products: balsam and resin. High deforestation rates in the area of distribution and the unregulated extraction of its resin and wood have led M. balsamum to be endangered or threatened. Its regeneration through seeds has been poorly studied, and there are no reports of germination and plasticity under controlled conditions. We evaluated the effect of scarification (longitudinal cut of the fruit and embryo fully exposed) and environmental factors (different levels of light intensities and changing temperatures) on seed germination and the development of seedlings. From the aforementioned, M. balsamum seeds are orthodox and show physical dormancy. In view of these characteristics, M. balsamum can be managed efficiently to initiate conservation programs and restoration in degraded land.
\end{abstract}

Keywords: Germinative capacity. Plant quality. Physical dormancy.

\section{EFEITO DA IRRADIÂNCIA, TEMPERATURA E ESCARIFIÇÃO NA CAPACIDADE GERMINATIVA E NO DESENVOLVIMIENTO DAS PLÃNTULAS DE Myroxylon balsamum (L.) HARMS}

\begin{abstract}
RESUMO - Myroxylon balsamum é uma valiosa árvore tropical, com madeira de boa qualidade e que também fornece produtos não madeiráveis, como bálsamo e resina. As elevadas taxas de desmatamento em sua distribuição natural e a extração não regulamentada de sua resina e madeira têm levado esta espécie à ameaça de extinção. A regeneração desta espécie tem sido pouco estudada, não havendo registros sobre a germinação e plasticidade de sua semente sob condições controladas. Neste trabalho avaliou-se o efeito da escarificação (corte longitudinal do fruto, exposição do embrião, testemunha não escarificada) e de fatores ambientais (diferentes níveis de intensidades luminosas e de regimes de temperatura) na capacidade germinativa da semente e no desenvolvimento das plântulas. A semente de M. balsamum é ortodoxa e os tratamentos de escarificação promoveram sua germinação. Pode haver uma latência física. A informação derivada deste trabalho pode apoiar programas de conservação e de restauração com M. balsamum.
\end{abstract}

Palavras-chave: Capacidade germinativa. Qualidade de planta. Dormência física.

\footnotetext{
"Corresponding author

${ }^{1}$ Received for publication in 03/02/2017; accepted in 05/16/2017.

Paper extracted from the master's thesis of the first author.

${ }^{2}$ Faculty of Agricultural Sciences, Universidad Central del Ecuador, Ecuador; scloayza@uce.edu.ec.

${ }^{3}$ Forest Science Division, Universidad Autónoma Chapingo, Texcoco, México; dantearturo@yahoo.com.

${ }^{4}$ Department of Soil, Area of Natural Resources, Universidad Autónoma Chapingo, Texcoco, México; elizahac@yahoo.com.mx.

${ }^{5}$ Program of Edaphology, Colegio de Postgraduados, Texcoco, México; jalamaraz@colpos.mx.
} 


\section{INTRODUCTION}

The genus Myroxylon belongs to the Leguminosae family, Papilionoideae subfamily. This genus presents two species: a) M. balsamum (L.) Harms, with the synonyms of $M$. balsamum var. pereirae, a native tropical tree widely distributed in evergreen and semi-evergreen tropical forests in southern Mexico, Central America and the western South American countries (INTERNATIONAL LEGUME DATABASE AND INFORMATION SERVICE, 2013) and b) $M$. peruiferum L. f., which is distributed mainly in a semi-deciduous forest in Brazil (BAGNATORI et al., 2015; DA SILVA et al., 2011).

The uses of $M$. balsamum are diverse. The wood is of good quality and is highly resistant, the tree is considered an important commercial timber source (MAEGLIN, 1991; ROCKWELL et al., 2007), distillates of its resin are used in perfumery (API, 2006), its balsam is utilized as an expectorant and for asthma treatment (ROBLES; OLIVEIRA; VILLALOBOS, 2000), and topically it is used in traditional medicine in the treatment of leishmaniasis (GACHET et al., 2010). M. balsamum was previously classified as endangered in Guatemala in the light of the extent of the occurrence of fragmentation (no more than five locations), with a continuous decline of: area of occupancy, area of habitat and number of locations or subpopulations (VIVERO et al., 2006). In Costa Rica M. balsamum has been considered in danger, its populations are very scarce, and its logging has been banned (JIMÉNEZ, 1999).

Overall in the southern region of Mexico this species is located in the dry forest and the evergreen tropical forest, where M. balsamum is distributed (PENNINGTON; SARUKHÁN, 2005); in addition, VERA (2003) mentioned that in Mexico this species was categorized as being at a medium level of threat due to illegal logging and forest fires.

Light intensity, day length requirements and photoperiod are factors that influence biomass production, stem growth, leaf properties and seed germination (BERLYN; CHO, 1999; SOUZA; VÁLIO, 2003b; LAMBERS; CHAPIN; PONDS, 2008). Conversely, the seed moisture content determines the eco-physiological type of the seeds as recalcitrant or orthodox (HONG; LININGTON; ELLIS, 1996). Seed drying after ripening is a natural mechanism that controls dormancy in tropical climates; dry seeds cannot germinate until biotic and abiotic factors induce seed scarification, which facilitates water imbibition. In addition, temperature and light are the main factors that regulate dormancy and germination (FINCH-SAVAGE; LEUBNER-METZGER, 2006). Despite the relevance of this species, its seed has been very scarcely studied.

The aims of this study were to (1) evaluate the effect of light intensity, temperature and mechanical scarification on seed germination and dormancy, (2) investigate the effect of light intensity and mechanical scarification on the initial development of $M$. balsamum seedlings, and (3) analyze the feasibility of using M. balsamum in the restoration of secondary successional stages.

\section{MATERIAL AND METHODS}

Fruits and seed collection were carried out in southeastern of Mexico, Salto de Eyipantla, $18^{\circ} 22^{\prime} 55 \mathrm{~N}$ and $95^{\circ} 12^{\prime} 17 \mathrm{~W}$ (altitude $167 \mathrm{~m}$ ). The seeds for the germination assays were collected from three individuals, the only accessible within the collection site. Seeds were selected (removing damaged seeds), dried under airflow at laboratory temperature and stored in laboratory environment conditions of $17{ }^{\circ} \mathrm{C}$. The weight from 40 fruits randomly selected, was registered.

The tetrazolium test to estimate the viability of the seeds was conducted ten days (with 20 seeds) and 146 days (with 20 seeds) after harvesting. The seeds were totally immersed in a $1 \%$ solution of 2,3,5-triphenyl-2H-tetrazolium chloride and placed in the dark for 24 hours at $30^{\circ} \mathrm{C}$. The red staining of the embryo and cotyledons were indicative of seed viability. The moisture content (dry basis) was determined ten days (with 20 seeds) and 146 days (with 20 seeds) after harvesting. Before the germination assay, the seeds were washed with water and soap, immersed in hypochlorite solution (10\%) for ten minutes and finally rinsed with distilled water.

For both germination assays, the controlled environment chamber was set with a $12 \mathrm{~h}$ photoperiod. The photosynthetically active radiation (PAR) was measured with an IRGA photosynthesis measuring device (BioScientific LTD). The experiment was carried out in the Forest Seeds Laboratory, División de Ciencias Forestales, Universidad Autónoma Chapingo, México by 2008.

For germination assay, with light intensities and mechanical scarification, shade nets were used to cover the containers and set the light intensities. Two levels of light intensities were set: $32 \mu \mathrm{mol} \mathrm{m} \mathrm{s}^{-1}$ (70\% shade net, covered containers) and $124 \mu \mathrm{mol} \mathrm{m} \mathrm{m}^{-2} \mathrm{~s}^{-1}$ (uncovered containers) and the temperature regime was $27 / 23{ }^{\circ} \mathrm{C}$ (day/night temperatures) in accordance with the photoperiod. For scarification there were three levels. Scarification was performed in two ways (Figure 1a): a longitudinal cut of the fruit in the hilum region (LC), removing all of the fruit structures and the seed coat until leaving the embryo and cotyledons exposed (E), and in addition there was no scarification (NS) as a control, only the wing of the fruit was cut off.

For each combination of levels of factors 
(scarification and light intensity) were settled five replicates with ten scarified fruits or seeds per replicate. A total of 300 scarified fruits were placed on sterile agrolite, germinative capacity was the study variable and was recorded along 75 days.

For germination assay, with light intensities and temperature regimes, two levels of light intensities were set: $32 \mu \mathrm{mol} \mathrm{m} \mathrm{m}^{-2}(70 \%$ shade net, covered containers) and $124 \mu \mathrm{mol} \mathrm{m} \mathrm{m}^{-2}$ (uncovered containers). The temperature regimes for the assays $\left(23 / 19{ }^{\circ} \mathrm{C}\right.$ and $\left.27 / 23{ }^{\circ} \mathrm{C}\right)$ were chosen on the basis of the average temperature over ten years for the months of November (coolest month) and May (warmest month) recorded at "Los Tuxtlas" Tropical Biology Station $\left(95^{\circ} 04^{\prime} \mathrm{W}\right.$ and $\left.18^{\circ} 34^{\prime} \mathrm{N}\right)$, where $M$. balsamum is distributed.

For this assay, were used seeds with embryo and cotyledons exposed (E). For each combination of levels of factors (light intensity and temperature regimes) were used five replicates with ten seeds per replicate. A total of 200 seeds were placed on sterile agrolite, germinative capacity was the study variable. The seeds were considered to be germinated when the radicle reached the length of the seed (approximately $1 \mathrm{~cm}$ ). Germinative capacity was recorded for 55 days.

For development of $M$. balsamum in greenhouse, seedlings from the germination assay with the longitudinal cut of the fruit (LC) and the embryo and cotyledons exposed (E), (Figure 1b) were used. Two light intensities of $587 \mu \mathrm{mol} \mathrm{m} \mathrm{m}^{-2} \mathrm{~s}^{-1}$ (50\% shade net) and $231 \mu \mathrm{mol} \mathrm{m} \mathrm{m}^{-2} \mathrm{~s}^{-1}(70 \%$ shade net) were set for this assay. For each combination of levels of factors (scarification x light intensity) were used three replicates with eight seedlings.

A total of 96 seedlings were transplanted to a growing media (mixture of $25 \%$ of organic matter from coffee and sugar cane husks decomposed for a year, $60 \%$ of soil and $15 \%$ of river sand). The growing media had a $\mathrm{pH}$ of 5.88 . The temperatures from June to October ranged between 10.16 and $24.20{ }^{\circ} \mathrm{C}$, and the average relative moisture was $61.6 \%$.

At the end of a cycle of five months (June to October), complete plants were used to measure: shoot dry weight $(\mathrm{g})$, root dry weight $(\mathrm{g})$, plant height $(\mathrm{cm})$, number of leaves, diameter $(\mathrm{mm})$, leaf area $\left(\mathrm{cm}^{2}\right)$, leaf area rate (LAR) (leaf area/total dry weight) $\left(\mathrm{m}^{2} \mathrm{~kg}^{-1}\right)$ (Figure $\left.1 \mathrm{c}\right)$; and estimate the seedling quality indicators: slenderness coefficient (height in $\mathrm{cm} /$ diameter in $\mathrm{mm}$ ), shoot/root weight ratio $\left(\mathrm{g} \mathrm{g}^{-1}\right)$ and Dickson quality index: total dry matter in grams/(slenderness coefficient + shoot/ root).

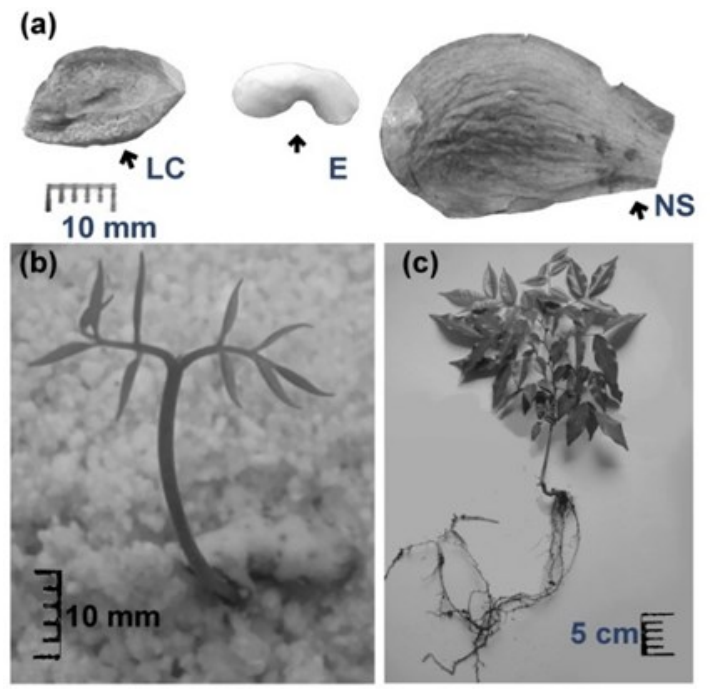

Figure 1. Scarification of Myroxylon balsamum fruits and plant material: (a) scarification with longitudinal cut of the fruit in the hilum region (LC), embryo and cotyledons exposed (E), no scarification (NS); (b) germinated seedling; (c) complete juvenile plant.

The analysis of variance (ANOVA) for the variables in each assay was performed using SAS (Statistical Analysis System ${ }^{\circledR}$ version 8 ). In the case of statistically significant differences among treatments, their means were compared using the Tukey test. A randomized complete block design was used for each assay. Germination percentage data were transformed into arcsine.

\section{RESULTS AND DISCUSSION}

Seed analysis showed an average fruit and seed weight of $9.358 \mathrm{~g}$ (107 fruits $/ \mathrm{kg})$ and $1.41 \mathrm{~g}$ (733 seeds $/ \mathrm{kg}$ ), respectively. Moisture content ten days after harvesting was $17.48 \%$, and for seeds stored for 146 days it was $5.52 \%$. Ten days after harvesting the percentage of viable seeds was $89 \%$, whereas after 146 days it was $73 \%$.

Within the fruit, we determined that the 
balsam is placed over the seed coat. During our research in Tezonapa (Veracruz, Mexico) we found that the balsam extracted is macerated with alcohol and used to cure skin infections and wounds in animals and for pain relief in humans (topical application). In this location, although work with this species is expensive, the wood is utilized for heavy-duty purposes, due to its hardness.

Our study showed high viability of the seeds at the beginning of the assay; four months later the viability had decreased by almost $16 \%$. Despite that reduction, the germination remained almost steady (over $80 \%$ ) when the seed moisture content was $5.52 \%$, suggesting that M. balsamum seeds behave as orthodox seeds. Similarly, Carvalho, Silva and Davide (2006) reported a germinative capacity of $65 \%$ for $M$. peruiferum seeds with a moisture content of $10.4 \%$. When the seeds of $M$. peruiferum were stored at $5{ }^{\circ} \mathrm{C}$ for three months, a reduction of the moisture content was recorded, but with no decrease in the germinative capacity.

Scarification of $M$. balsamum increased germination, however this was not affected by light intensities (Table 1). The germinative capacity when complete scarification had been done (exposed embryo and cotyledons) was reached in 37 days, 52 days when a longitudinal cut was made, and 72 days for the nonscarified fruit (Figure 2).

Table 1. Germinative capacity of Myroxylon balsamum seed in response to scarification and light intensities. (E) embryo and cotyledons exposed, (LC) longitudinal cut of the fruit, (NS) no scarification.

\begin{tabular}{|c|c|}
\hline Factors and levels & Germination (\%) \\
\hline \multicolumn{2}{|l|}{ Light intensities (L): } \\
\hline $124 \mu \mathrm{mol} \mathrm{m}^{-2} \mathrm{~s}^{-1}$ & $64 \mathrm{a} *$ \\
\hline $32 \mu \mathrm{mol} \mathrm{m} \mathrm{s}^{-2}$ & $53 \mathrm{a}$ \\
\hline$P$ & 0.0751 \\
\hline \multicolumn{2}{|l|}{ Scarification (S): } \\
\hline $\mathrm{E}$ & $87 \mathrm{a}$ \\
\hline LC & $76 \mathrm{a}$ \\
\hline NS & $13 \mathrm{~b}$ \\
\hline$P$ & $<0.0001$ \\
\hline \multicolumn{2}{|l|}{ L x S: } \\
\hline$P$ & 0.5615 \\
\hline
\end{tabular}

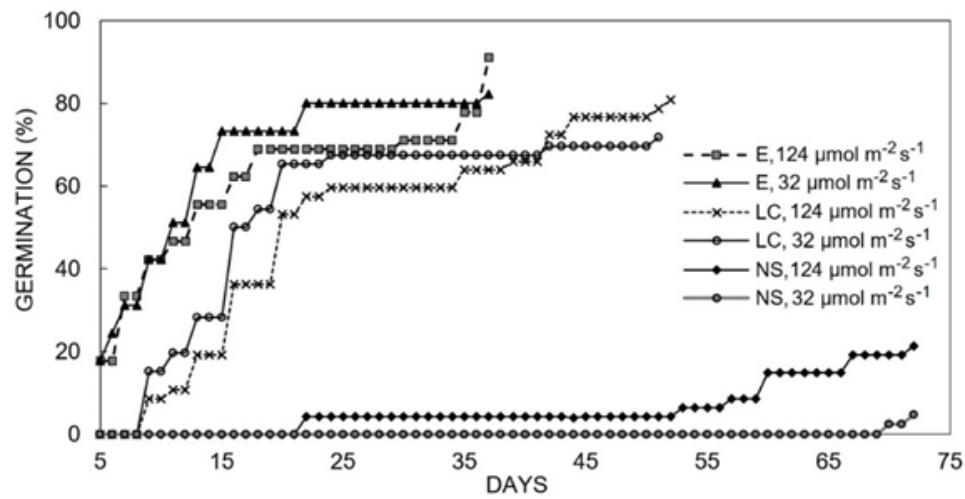

Figure 2. Cumulative germination percentage of Myroxylon balsamum seeds with three types of scarification and two levels of light intensities at a temperature regime of $27 / 23^{\circ} \mathrm{C}$.

One classification for seed dormancy is based on five classes with different characteristics; within these classes is included the physical dormancy (PY), (BASKIN; BASKIN, 2004). The PY is caused by the water-impermeable seed coat and is common in the Leguminosae family, including Papilionoideae
(BASKIN; BASKIN; LI, 2000). Our results show that $M$. balsamum seeds have a PY behavior; furthermore, the scarification method herein described eliminated the PY imposed by the pericarp and facilitated water imbibition, increasing the germination percentage and thereby reducing the 
time for seed germination.

The germination response to scarification has been reported for legumes with a hard seed coat, e.g. the tropical leguminous trees Plathymenia reticulata Benth and Senna multijuga Rich. showed an increase in the germinative capacity of $35.5 \%$ and $68.5 \%$, respectively (LACERDA et al., 2004). Similarly, for the multipurpose tree Lannea microcarpa (Engel \& $\mathrm{K}$. Krause), the germinative capacity increase ranged between 40 and $90 \%$, depending on the mechanical scarification procedure (NEYA; HOEKSTRA; GOLIVINA, 2008). Our results are consistent with the above-mentioned researches; although light made no difference to germination, scarification increased the germinative capacity of $M$. balsamum for exposed embryo (87\%) and longitudinal cut (76\%).

Werker (1980) stated that PY could be influenced by water resistance substances (such as waxes) that impregnate the seed coat and thus avoid water infiltration during seed ripening. As we identified that the balsam was found on the seed coat, and is non-water miscible, it is feasible that this substance keeps water out of the reach of the seed, contributing to the PY in $M$. balsamum seeds. The chemical composition of balsams is essentially insoluble in water, and due to this, the analysis of the main components of the balsam extracted from $M$. balsamum must be made from organic solvents (CUSTÓDIO; VEIGA-JUNIOR, 2012).

The positive response of the seeds to scarification facilitates the potential use of M. balsamum for restoration of degraded tropical lands. Large seeds (weight $>1 \mathrm{~g}$ ) from shade-tolerant species were suitable for restoration of degraded land because the species showed higher germination and survival percentages than small-seeded and gap-dependent species (HOOPER; CONDIT; LEGENDRE, 2002). Another advantage derived from the scarification of $M$. balsamum could be that scarified seeds may be sown directly over the degraded land and germinate faster, so the scarification of seeds could limit the exposure time to seed pathogens and increase the speed of seedling settlement.

The positive response in the germination of M. balsamum seeds to scarification with a longitudinal cut (LC) in the hilum region (76\%) could be a success if we are planning direct sowing in the restoration site. In this case, the longitudinal cut breaks the physical dormancy and enhances the water imbibition. At the same time, the pericarp and seed coat may protect the embryo to some degree against possible seed herbivores; seeds with this treatment could be sown directly over lands under secondary succession that have light intensities similar to the one in our study $\left(124 \mu \mathrm{mol} \mathrm{m} \mathrm{m}^{-2} \mathrm{~s}^{-1}\right)$, similar to emulating the luminosity from a small gap $\left(200 \mathrm{~m}^{2}\right)$.

For germination assay, with light intensities and temperature regimens, there were no significant differences among the studied factors of light intensities and temperature regimes in M. balsamum germination percentage (Table 2). Nevertheless, the cumulative germination percentage in the $23 / 27^{\circ} \mathrm{C}$ temperature regime was reached 19 days before that in the $19 / 23^{\circ} \mathrm{C}$ regime (Figure 2 ).

Table 2. Effects of light intensities and temperature regimes in Myroxylon balsamum seed germination.

\begin{tabular}{rc}
\hline Factors and levels & Germination (\%) \\
\hline Light intensities (L): & \\
$124 \mu \mathrm{mol} \mathrm{m} \mathrm{m}^{-1}$ & $84 \mathrm{a} *$ \\
$32 \mu \mathrm{mol} \mathrm{m} \mathrm{s}^{-1}$ & $85 \mathrm{a}$ \\
$P$ & 0.7755 \\
Temperature (T): \\
$19 / 23^{\circ} \mathrm{C}$ & $82 \mathrm{a}$ \\
$23 / 27^{\circ} \mathrm{C}$ & $87 \mathrm{a}$ \\
$P$ & 0.5678 \\
\hline *Values with different letters are \\
statistically different; Tukey $(P \leq 0.05)$.
\end{tabular}

Shade-tolerant species can germinate, grow and survive in low light (OSUNKOYA et al., 1994). In our study, M. balsamum germinated well in both low and high luminosities, which emulated the luminosity of an understory and the luminosity of a small gap $\left(200 \mathrm{~m}^{2}\right)$ from 9:00 to $13: 00 \mathrm{pm}$ (CHAZDON; FETCHER, 1984). Our results show that M. balsamum follows a gap-dependent trend mentioned by Popma, Bongers and Werger (1992), where this kind of species has the ability to survive for prolonged periods as juveniles in the shade and which also requires small gaps to pass through one or several stages in their life cycle. 


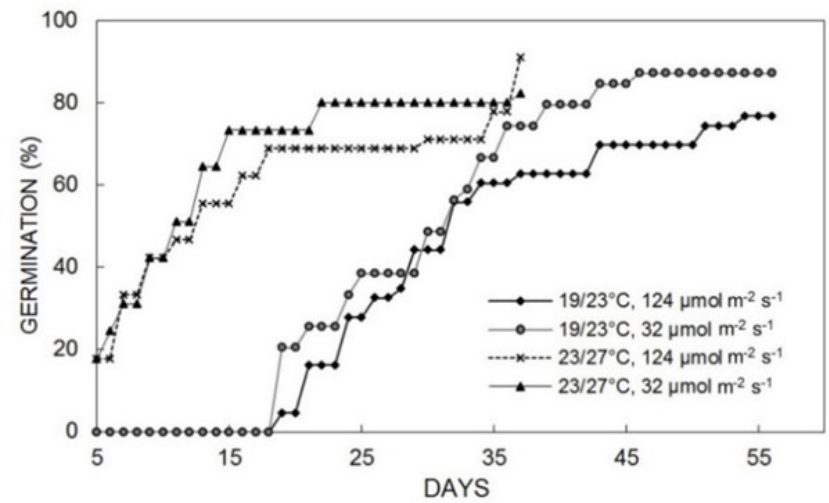

Figure 3. Cumulative germination percentage of Myroxylon balsamum seeds, embryo and cotyledons exposed (E), under different light intensities and temperature regimes.

Our results showed that $M$. balsamum had the same germination pattern as that reported by Figliolia, Aguiar and Da Silva (2006) for $M$. peruiferum $(65 \%$ germination in the absence of light and $67 \%$ germination with $367 \mu \mathrm{mol} \mathrm{m} \mathrm{m}^{-2}$ ) under a similar alternated temperature regimen $\left(20 / 30{ }^{\circ} \mathrm{C}\right)$. Finally, Souza and Válio (2001) suggested the same behavior for $M$. peruiferum in low light intensities (67\% germination in darkness and $72 \%$ germination with $14 \mu \mathrm{mol} \mathrm{m} \mathrm{m}^{-2} \mathrm{~s}^{-1}$ ) with a constant temperature of $25{ }^{\circ} \mathrm{C}$.

For development of $M$. balsamum in greenhouse, there were significant differences in stem diameter for the interaction scarification $\mathrm{x}$ light intensities $(p=0.0296)$, and for the number of leaves for the scarification factor $(p=0.0382)$. Significant differences were observed for the slenderness coefficient $(\mathrm{p}=0.0109)$ and leaf area ratio $(p=0.0089)$ for the light intensity factor.

A higher number of leaves was obtained with LC (62 leaves) than with E scarification (51 leaves) (Figure $4 \mathrm{a})$, and the highest stem diameter $(3.5 \mathrm{~mm})$ was obtained when exposing the trees to a light intensity of $587 \mu \mathrm{mol} \mathrm{m} \mathrm{m}^{-2} \mathrm{~s}^{-1}$ and LC scarification (Figure 4b).

The best (lowest) slenderness coefficient was reached with a light intensity level of $587 \mu \mathrm{mol} \mathrm{m} \mathrm{m}^{-2} \mathrm{~s}^{-1}$ (Figure $4 \mathrm{c}$ ). On the other hand, a light intensity level of $231 \mu \mathrm{mol} \mathrm{m} \mathrm{m}^{-2} \mathrm{~s}^{-1}$ yielded the highest leaf area (Figure 4d).
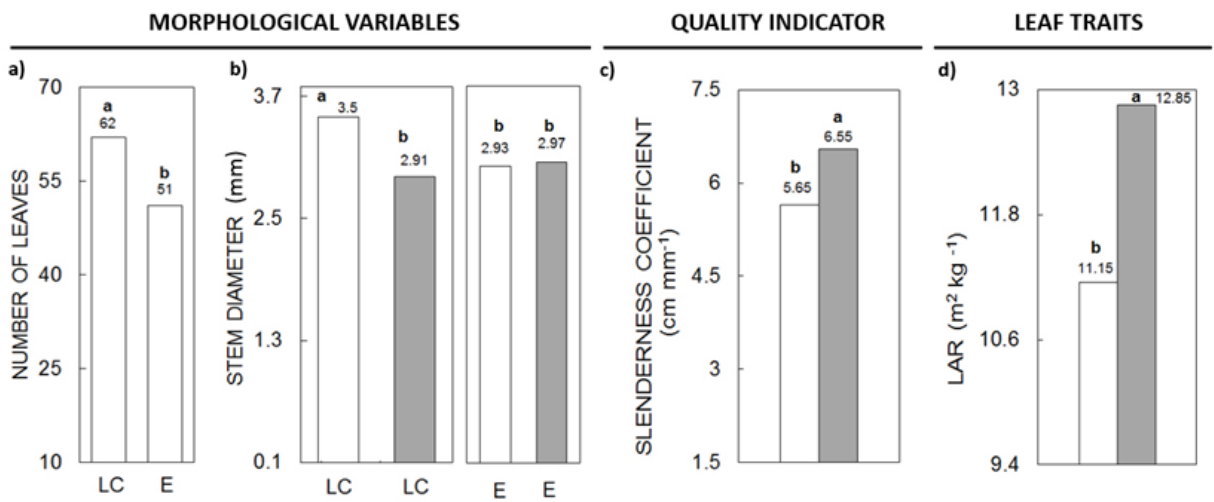

Figure 4. Significant differences in growth parameters during the development of Myroxylon balsamum seedlings in greenhouse; Tukey: $p \leq 0.05$. (a) Effect of scarification on the number of leaves; (LC) longitudinal cut, (E) embryo and cotyledons exposed. (b) Effect of light intensities and scarification on stem diameter $\left(587 \mu \mathrm{mol} \mathrm{m}^{-2} \mathrm{~s}^{-1}\right.$ white bars, $231 \mu \mathrm{mol}$ $\mathrm{m}^{-2} \mathrm{~s}^{-1}$ gray bars). (c) Effect of light intensities on the slenderness coefficient (587 $\mu \mathrm{mol} \mathrm{m} \mathrm{s}^{-2} \mathrm{~s}^{-1}$ white bars, $231 \mu \mathrm{mol} \mathrm{m} \mathrm{m}^{-2} \mathrm{~s}^{-1}$ gray bars). (d) Effect of light intensity on leaf area ratio (LAR) $\left(587 \mu \mathrm{mol} \mathrm{m}^{-2} \mathrm{~s}^{-1}\right.$ white bars, $231 \mu \mathrm{mol} \mathrm{m}^{-2} \mathrm{~s}^{-1}$ gray bars).

The remaining measured variables did not show significant differences $(\mathrm{p}>0.05)$ (Table 3$)$.

In M. balsamum, the LAR was higher with the lowest light intensity. Souza and Válio (2003a) described a similar response in $M$. peruiferum leaves; the specific leaf area (SLA) reached the highest value under the shade treatment, and the low light intensity level influenced this Myroxylon species to express typical responses of answers of shade tolerance. This trend is explained by Lambers, Chapin and Ponds (2008), who state that the plants growing under shade tend to invest more resources in their leaves, to generate more photosynthetic surface area, mainly as a response to the low light intensities levels. This type of adaptive leaf characteristic improves its efficiency for light absorption in atmospheres of low luminosity (SOUZA; VÁLIO, 2003b; GRATANI; COVONE; LARCHER, 2006). 
S. L. CABEZAS et al.

Table 3. Averages of Myroxylon balsamum seedling growth variables in greenhouse.

\begin{tabular}{lcccc}
\hline Sacarification + Light intensities & $\begin{array}{c}\text { Plant height } \\
(\mathrm{cm})\end{array}$ & $\begin{array}{c}\text { Root dry weight } \\
(\mathrm{g})\end{array}$ & $\begin{array}{c}\text { Shoot dry weight } \\
(\mathrm{g})\end{array}$ & $\begin{array}{c}\text { Leaf area } \\
\left(\mathrm{cm}^{2}\right)\end{array}$ \\
\hline $\mathrm{E}+587 \mu \mathrm{mol} \mathrm{m}^{-2} \mathrm{~s}^{-1}$ & 15.65 & 0.36 & 1.35 & 199.02 \\
$\mathrm{E}+231 \mu \mathrm{mol} \mathrm{m} \mathrm{s}^{-1}$ & 20.71 & 0.40 & 1.43 & 238.33 \\
$\mathrm{LC}+587 \mu \mathrm{mol} \mathrm{m}^{-2} \mathrm{~s}^{-1}$ & 19.90 & 0.56 & 1.86 & 257.14 \\
$\mathrm{LC}+231 \mu \mathrm{mol} \mathrm{m}^{-2} \mathrm{~s}^{-1}$ & 19.43 & 0.42 & 1.51 & 245.76 \\
\hline
\end{tabular}

A light intensity of $587 \mu \mathrm{mol} \mathrm{m}^{-2} \mathrm{~s}^{-1}$ influenced the stem diameter; this intensity is common for a tropical forest, as previously described by Chazdon and Fetcher (1984) within a clearing site of 0.5 ha. In addition, Popma and Bongers (1988) reported that seedlings of Lonchocarpus guatemalensis Benth grown in small and large gaps showed higher diameters $(3.9 \mathrm{~mm}$ and $5.0 \mathrm{~mm}$, respectively) than forest understory seedlings (stem diameter of $3.0 \mathrm{~mm}$ ).

Together, the environmental changes that induced variations in the phenotype could be interpreted as the phenotypic plasticity of $M$. balsamum. This phenotypic plasticity is considered a short-term adaptation under environmental heterogeneity (PIGLIUCCI; MURREN; SCHLICHTING, 2006); a typical response of phenotypic plasticity is the modification of leaf traits to the light gradient from a heterogeneous light environment within a forest canopy (ROZENDAAL; HURTADO; POORTER, 2006).

The lowest slenderness coefficient was obtained when the seedlings were exposed to the higher light intensity too. Previous studies with tree species from temperate climates showed that lower slenderness coefficients are associated with stouter seedlings (CARDILLO; BERNAL, 2006; HAASE, 2006). The information about the slenderness coefficient related to tropical trees is scarce, and this study could be used as a reference for further research; reducing the slenderness coefficient in a greenhouse by increasing light intensity could produce more vigorous seedlings, and this could favor their establishment and survival in the field.

For a restoration purpose with M. balsamum, it is also possible to take advantage of the phenotypic plasticity in leaf traits (LAR) under low luminosity of $231 \mu \mathrm{mol} \mathrm{m} \mathrm{m}^{-2}$, this offers the possibility of use this species in restoration sites under the canopy of pioneers and different gap sizes in the tropical rain forest and tropical deciduous forest within its ecological range.

\section{CONCLUSIONS}

Mechanical scarification with embryo and cotyledons exposed, and longitudinal cut of the fruit have a favorable effect on the germinative capacity of $M$. balsamum seeds because it breaks its physical dormancy (PY) and accelerate seed germination.

With a higher temperature, the germination capacity of the seeds of $M$. balsamum is reached 19 days earlier than with a lower temperature.

The high light intensity and the mechanical scarification of the seed influence the initial development of the seedlings of M. balsamum in greenhouse, as they show a larger stem diameter, a better coefficient of slenderness, and greater number of leaves, in addition a higher leaf area rate with low luminosity, suggesting a capacity of adaptation of this species to different intensities of light.

$M$. balsamum can be used in conservation programs and in the restoration of a secondary forest, provided that the described characteristics are efficiently handled, especially the scarification of the seeds.

\section{ACKNOWLEDGMENTS}

We thank the Graduate Program in Agroforestry for Sustainable Development, and the Graduate Program in Forest Sciences, University of Chapingo, for supporting our travels to the seed collection sites and for their support during germination assays. Finally, we thank Aurelio Fierros-González, Fabio Idrovo and Jorge Alatorre for their useful help and comments and Dr. Antonio Carlos Batista for his fine translation into Portuguese.

\section{REFERENCES}

API, A. M. Only Peru balsam extracts or distillates are used in perfumery. Contact Dermatitis, Erlangen, v. 54, n. 3, p. 131-179, 2006.

BAGNATORI, A. L. et al. A revision of the genus Myroxylon (Leguminosae: Papilionoidea). Kew Bulletin, London, v. 70, n. 48, p. 1-12, 2015.

BASKIN, J. M.; BASKIN, C. C. A classification system for seed dormancy. Seed Science Research, Cambridge, v. 14, n. 1, p. 1-16, 2004.

BASKIN, J. M.; BASKIN, C. C.; LI, X. Taxonomy, 
anatomy and evolution of physical dormancy in seeds. Plant Species Biology, Sapporo, v. 15, n. 2, p. 139-152, 2000.

BERLYN, G. P.; CHO, J. Light, moisture, and nutrient use by plants. In: ASHTON, M.S; MONTAGNINI. (Eds.). The silvicultural basis for agroforestry systems. Florida: CRC, 1999. cap. 2, p. 9-39.

CARDILlO, E.; BERNAL, J. C. Morphological response and growth of cork oak (Quercus suber L.) seedlings at shade levels. Forest Ecology and Management, New South Wales, v. 222, n. 1-3, p. 296-301, 2006.

CARVAlHO, L. R.; SILVA, E. A.; DAVIDE, A. C. Classificação de sementes florestais quanto ao comportamento no armazenamento. Revista Brasileira de Sementes, Londrina, v. 28, n. 2, p. 1525, 2006.

CHAZDON, R. L.; FETCHER, N. Photosynthetic light environments in a lowland tropical rain forest in Costa Rica. Journal of Ecology, London, v. 72, n. 2, p. 553-554, 1984.

CUSTÓDIO, D. L.; VEIGA-JUNIOR, V. F. True and common balsams. Brazilian Journal of Pharmacognosy, Curitiba, v. 22, n. 6, p. 1372-1383, 2012.

DA SILVA, T. D. et al. Potential of medicinal plants from the Brazilian semi-arid region (Caatinga) against Staphylococcus epidermidis planktonic and biofilm lifestyles. Journal of Ethnopharmacology, Pretoria, v. 137, n. 1, p. 327-335, 2011.

FIGLIOLIA, M. B.; AGUIAR, I. B.; DA SILVA, A. Germinação de sementes de Lafoensia glyptocarpa Koehne (mirindiba-rosa), Myroxylon peruiferum L. f. (cabreúva-vermelha) e Cedrela fissilis Vell. (cedrorosa). Revista do Instituto Florestal, São Paulo, v. 18, n. 1, p. 49-58, 2006.

FINCH-SAVAGE, W. E.; LEUBNER-METZGER, G. Seed dormancy and the control of germination. New Phythologist, Lancaster, v. 171, n. 3, p. 501523, 2006.

GACHET, M. et al. Assessment of anti-protozoal activity of plants traditionally used in Ecuador in the treatment of leishmaniasis. Journal of Ethnopharmacology, Graz, v. 128, n. 1, p. 184-197, 2010.

GRATANI, L.; COVONE, F.; LARCHER, W. Leaf plasticity in response to light of three evergreen species of the Mediterranean maquis. Trees, Vancouver, v. 20, n. 5, p. 549-558, 2006.
HAASE, D. L. Morphological and physiological evaluations of seedling quality. In: RILEY, L. E.; DUMROESE, R. K.; LANDIS, T. D. (Eds.). National Proceeding: Forest and Conservation Nursery Associations. Fort Collins: U.S. Department of Agriculture, Forest Service, Rocky Mountain Research Station, 2006. p. 3-8.

HONG, T. D.; LININGTON, S.; ELLIS, R. H. Seed storage behaviour: a compendium. Rome: International Plant Genetic Resources Institute, 1996, $103 \mathrm{p}$.

HOOPER, E.; CONDIT, R.; LEGENDRE, P. Responses of 20 native tree species to reforestation strategies for abandoned farmland in Panama. Ecological Applications, Washington, v. 12, n. 6, p. 1626-1641, 2002.

INTERNATIONAL LEGUME DATABASE AND INFORMATION SERVICE - ILDIS. Myroxylon balsamum (L.) Harms. Available on: <http:// www.ildis.org/LegumeWeb>. Acess in: 01 feb. 2013.

JIMÉNEZ, Q. Árboles Maderables en Peligro de Extinción en Costa Rica. 2. ed. Santo Domingo de Heredia: INCAFO, 1999. 187 p.

LACERDA, D. R. et al. Seed-dormancy variation in natural population of two tropical leguminous tree species: Senna multijuga (Caesalpinoideae) and Plathymenia reticulate (Mimosoideae). Seed Science Research, Cambridge, v. 14, n. 2, p. $127-$ $135,2004$.

LAMBERS, H.; CHAPIN, F. S.; PONDS, T. L. Plant physiological ecology. 2. ed. New York: Springer Science + Business Media LLC.N.Y, 2008, $571 \mathrm{p}$.

MAEGLIN, R. R. Forest products from Latin America: an almanac of the state of the knowledge and the state of the art. Madison: U.S. Department of Agriculture, Forest Service, Forest Products Laboratory, 1991, 151 p.

NEYA， O.; HOEKSTRA， F.; GOLIVINA， E. Mechanism of endocarp-imposed constraints of germination of Lannea microcarpa seeds. Seed Science Research, Cambridge, v. 18, n. 1, p. 13-24, 2008.

OSUNKOYA, O. et al. Influence of seed size and seedling ecological attributes on shade-tolerant of rain-forest tree species in Northern Queensland. Journal of Ecology, London, v. 82, n. 1, p. 149 163, 1994.

PENNINGTON, T.; SARUKHÁN, J. Árboles 
Tropicales de México: Manual para la Identificación de las Principales Especies. 3. ed. México: UNAM y Fondo De Cultura Económica, 2005. $523 \mathrm{p}$.

PIGLIUCCI, M.; MURREN, C. J; SCHLICHTING, C. D. Phenotypic plasticity and evolution by genetic assimilation. The Journal of Experimental Biology, Bern, v. 209, n. 12, p. 2362-2367, 2006.

POPMA, J.; BONGERS, F. The effect of canopy gaps on growth and morphology of seedlings of rain forest species. Oecology, Berlin, v. 75, n. 4, p. 625 $632,1988$.

POPMA, J.; BONGERS, F.; WERGER, M. J. A. Gap-dependence and leaf characteristics of trees in a tropical lowland rain forest in Mexico. Oikos, Copenhagen, v. 63, n. 2, p. 207-214, 1992.

ROBLES, G. R.; OLIVEIRA, K.; VILLALOBOS, R. Evaluación de los productos forestales no madereros en América Central. Roma: FAO, 2000. 96 p.

ROCKWELL, C. et al. Future crop tree damage in a certified community forest in southwestern Amazonia. Forest Ecology and Management, New South Wales, v. 242, n. 2-3, p. 108-118, 2007.

ROZENDAAL, D. M. A.; HURTADO, V. H.; POORTER, L. Plasticity in leaf traits of 38 tropical tree species in response to light; relationships with light demand and adult stature. Functional Ecology, London, v. 20, n. 2, p. 207-216, 2006.

SOUZA, R. P.; VÁLIO, I. F. M. Seed size, seed germination, and seedling survival of Brazilian tropical tree species differing in successional status. Biotropica, Gainesville, v. 33, n. 11, p. 447-457, 2001.

SOUZA, R. P.; VÁLIO, I. F. M. Seedling growth of fifteen Brazilian tropical tree species differing in successional status. Brazilian Journal of Botany, São Paulo, v. 26, n. 1, p. 35-47, 2003 a.

SOUZA, R. P.; VÁLIO, I. F. M. Leaf optical properties as affected by shade in saplings of six tropical tree species differing in successional status. Brazilian Journal of Plant Physiology, Campos dos Goytacazes, v. 15, n. 1, p. 49-54, 2003b.

VERA, G. Estado de la diversidad biológica de los árboles y bosques en el sur y sureste de México. Documentos de trabajo: recursos genéticos forestales. FGR/61S. Roma: Servicio de Desarrollo de Recursos Forestales FAO, 2003. 52 p.
VIVERO, J. L. et al. The red list of trees of Guatemala. Cambridge: Fauna \& Flora International, 2006. $48 \mathrm{p}$.

WERKER, E. Seed dormancy as explained by the anatomy of embryo envelopes. Israel Journal of Botany, Bet-Dagan, v. 29, n. 1-4, p. 22-44, 1980. 